\title{
Democratic Innovations in Central and Eastern Europe
}

Sergiu Gherghina, Joakim Ekman \& Olena Podolian (red.)

London: Routledge 2020

131 sider. ISBN 9780367421670

Omtalt av Elisabeth Bakke [dr. polit., førsteamanuensis ved Institutt for statsvitskap, Universitetet i Oslo, elisabeth.bakke@stv.uio.no]

Boka Democratic Innovations in Central and Eastern Europe er inndelt i åtte kapittel: eit innleiingskapittel om «demokratiske innovasjonar» skrive av redaktørane, fire kapittel om folkeavstemmingar, to kapittel om deliberativ praksis og eitt om borgarmedverknad ved hjelp av teknologi (E-deltaking). Empirisk dekkjer boka land i Sentral- og Aust-Europa med varierande demokratistatus - frå reine hybridregime til meir eller mindre fungerande demokrati. Kapitla i boka har tidlegare vore publisert som artiklar i tidsskriftet Contemporary Politics (2019). Det er litt uklart kva for meirverdi ei bokutgjeving gir.

I innleiingskapitlet definerer redaktørane «demokratisk innovasjon» som «institusjonar som er meint å skulle styrke borgarmedverknad i den politiske vedtaksprosessen» (s. 2). Dei er innovasjonar fordi dei avvik frå det tradisjonelle representative demokratiet. Redaktørane skil mellom tre typar demokratiske innovasjonar: folkeavstemmingar, deliberative praksisar og E-deltaking. Forskinga på politisk deltaking har tradisjonelt i stor grad fokusert på vestlege demokrati, samtidig som borgarmedverknad har vorte oppfatta som eit meir marginalt fenomen i Sentral- og AustEuropa. Boka bidreg dermed til å utvide det geografiske spennet og til å nyansere bildet når det gjeld politisk deltaking i desse landa.

Av dei tre typane demokratiske innovasjonar er det folkeavstemmingar som er best dekt i litteraturen frå før. Vinklinga i kapitla som handlar om dette varierer, men alle viser at folkeavstemmingar i liten grad bidrar til å styrke demokratiet. I staden blir dei reiskapar i hendene på partia eller støttespelarane deira, og det gjeld ikkje berre i dei to hybridregima som er behandla i kapittel 4 og 5 (Moldova og Ungarn). Fordi det er minimumskrav til deltaking for at resultatet skal vera gyldig, er det gjerne meir effektivt for nei-sida å oppmode til boikott av folkeavstemmingane enn å kjempe for synet sitt. Dermed blir dei fleste kjent ugyldige på grunn av låg deltaking. Dette har også konsekvensar for forklaringar av utfall. 
Kapittel 2 er eit interessant og velskrive bidrag om folkeavstemminga i Slovakia i 2015, forfatta av Miroslav Nemčok, Peter Spáč og PetrVoda. Folkeavstemminga var uvanleg i den forstand at den var initiert av Familiealliansen, ein frivillig organisasjon som er opptatt av tradisjonelle familieverdiar, og handla om å reservere ekteskapet for mann og kvinne, forby homofil adopsjon og sikre barn mot å måtte delta i seksualundervisning i skulen mot familiens vilje. Det er tidlegare godt kjent frå litteraturen at veljarane høyrer på partiet sitt når det gjeld standpunkt i folkeavstemmingar. Forfattarane syner her at partiets standpunkt var viktigare for å forklare deltaking i folkeavstemminga enn for å forklare kva for standpunkt dei tok. Dette heng saman med den slovakiske grunnlovas krav om femti prosent deltaking.

Kapittel 3 tar for seg den same folkeavstemminga, men samanliknar med folkeavstemmingar i Bulgaria (om valordning og partifinansiering) og Polen (om innføring av enkeltkrinsar i val til Sejm). Ingen av desse folkeavstemmingane var gyldige på grunn av låg deltaking. Forfattarane har gjort ei surveyundersøking med utgangspunkt i snøballmetodikk (511 respondentar for alle tre land samla), og finn at dei som tykte kampanjen knytt til folkeavstemmingane var informativ også var mest tilbøyelege til å stemme for. Det er i og for seg interessant nok, men talet på respondentar er, som forfattarane sjølve er inne på, for lågt til at resultata av analysen er generaliserbare.

I kapittel 5 tar Zoltán Pállinger for seg direkte demokrati i Ungarn sidan 1989, altså både før og etter at den demokratiske tilbakegangen starta i 2010. Kapitlet gir eit interessant innblikk i forholdet mellom representativt demokrati og folkeavstemmingar, og særleg korleis Fidesz har kolonisert også direkte demokrati. Endringar i regelverket bidrog elles til at det har vorte halde berre ei folkeavstemming etter 2010, og den var initiert av regjeringa. Det siste bidraget om folkeavstemmingar (kapittel 4) handlar om det mislykka forsøket på å avsetja ordføraren i Moldovas hovudstad Chișinău gjennom folkeavstemming (såkalla re-call).

Dei to neste kapitla handlar om deliberativ praksis. I kapittel 6 reiser Dmytro Volodin spørsmålet om korleis deliberativ praksis, her eksemplifisert gjennom borgarmedverknad i budsjettering i Chernivtsi, Ukraina, påverkar tillit, og viser at tilliten til ordføraren og bystyret auka som følgje av deltaking sjølv i eit hybridregime som Ukraina. Utgangspunktet for kapittel 7 er derimot nedgangen i deltaking i naboskapsråd i Timișoara, Romania, som tidlegare har fătt prisar for innovasjon. Folk trøytnar og droppar ut over tid, spesielt om dei ikkje føler at dei får noko ut av det, konkret eller i form av sosial kontakt. Det siste kapittelet i boka handlar om E-deltaking og har empiri frå Serbia. Kapittelet viser at ingen av dei tre omtalte IKT-prosjekta (e-Participation, Ask your MP/Local Representative, Networking of Local Communities) var særleg vellykka når det gjeld å auke borgarmedverknad.

Samla sett kastar boka nytt lys over korleis alternative deltakingsformer fungerer i meir eller mindre demokratiske land i Sentral- og Aust-Europa. Forfattarane tar i bruk varierte metodar, og mange av funna er interessante i seg sjølv, men eg skulle nok ønskje at redaktørane og/eller forfattarane i større grad hadde reflektert over i 
kva grad demokratisk innovasjon er særleg treffande omgrepsbruk i ein kontekst der hovudinntrykket er at «innovasjonane» i grunnen ikkje bidreg noko særleg korkje til auka deltaking eller meir demokrati. Deltakinga i folkeavstemmingar er notorisk låg, noko som fører til at dei langt fleste blir kjent ugyldige. Det mest ekstreme eksemplet i boka er folkeavstemminga om enkeltkrinsar i Polen i 2015, der under åtte prosent møtte fram. Forsøka på å auke borgarmedverknad ved hjelp av teknologi i Serbia var heller ikkje særleg vellykka, og sjølv det som fungerte på kort sikt - som naboskapsråd i Timișoara - tapte oppslutning på lengre sikt. Kanskje fungerer slike «innovasjonar» annleis i hybridregime enn i demokrati. Det burde vore utforska. 